\title{
ETNIK RELIGIUS MAHASISWA MINORITAS DALAM KOMUNITAS MUSLIM
}

\author{
Robeet Thadi ${ }^{1}$
}

\begin{abstract}
Abstrak
Agama adalah sebuah keyakinan dan kesadaran diri yang sangat pribadi, sebagai makhluk sosial, interaksi antar manusia tidak bisa dihindari yang meretas batas dan ruang religius. Dalam perspektif interaksi simbolik, pribadi seseorang dapat dilihat dari kesadaran dan motiv individu yang bersiafat unik dan dinamis. Konsep kesadaran diri dimungkinkan dapat dilihat dalam diri individu dalam sebuah komunitas. Begitu pula hal yang terjadi pada mahasiswa minoritas dalam komunitas muslim, mereka akhirnya mengembangkan konsep kesadaran diri dan motiv individu masingmasing dalam interaksinya.
\end{abstract}

Kata Kunci: mahasiswa, minoritas, religi, interaksi simbolik

\section{PENDAHULUAN}

FENOMENA pluralitas adalah suatu kenyataan yang tak terbantahkan, hal tersebut telah menjadi bagian dari sejarah panjang perjalanan hidup bangsa. Bahkan bangsa Indonesia sering disebut sebagai bangsa yang paling majemuk di dunia, realitas tersebut telah memberikan pemandangan indah yang selalu mewarnai aktivitas kepluralan kehidupan berbangsa. Setiap saat kita disuguhi dengan nuansa perbedaan dari warga negara. Masing-masing etnis menampilkan budaya dan tradisi yang berbeda. Setiap agama dan kepercayaan mempraktekkan ajarannya masing-masing dengan prosesi dan tata cara yang berbeda satu dengan yang lainnya.

Senada dalam kehidupan pendidikan, agama merupakan mata kuliah wajib setiap sekolah dan perguruan tinggi. Beberapa tahun terakhir, pola pendekatan pendidikan lebih diarahkan pada pendekatan Ilahiyah yang bersifat religi. Tak terkecuali pada tingkatan pendidikan yang dianggap sudah dewasa sekalipun setingkat pascasarjana, juga melakukan hal yang sama. Ada yang menarik di sini, ketika ada sebagian mahasiswa yang memiliki kepercayaan minoritas, tentunya pola interaksi dalam budaya yang berbeda mempunyai porsi tersendiri untuk diteliti. Bagaimana mereka berinteraksi dalam menjalin hubungan, tentunya interaksi dalam pendekatan komunikasi merupakan bagian yang tidak dapat dipisahkan.

Salah satu identitas manusia adalah manusia sebagai makhluk sosial yang tidak dapat hidup tanpa berkomunikasi dengan manusia lainnya, karena untuk memenuhi kebutuhan hidup manusia harus berinteraksi dengan orang lain. Terlebih lagi dalam dunia yang global seperti sekarang ini, komunikasi tidak saja dilakukan oleh orang yang memiliki satu karakteristik dengan budaya yang sama,

\footnotetext{
${ }^{1}$ Dosen Ilmu Komunikasi IAIN Bengkulu, Almuni Magister Ilmu Komunikasi Universitas Padjadjaran.
} 
tetapi komunikasi juga dilakukan oleh orang lain yang memiliki karakteristik dengan budaya dan kepercayaan yang berbeda-beda. Cara kita berkomunikasi sebagian besar dipengaruhi oleh budaya, orang-orang dari budaya yang berbeda kemungkinan besar akan berkomunikasi dengan cara yang berbeda pula (Devito, 1997: 481).

Bagaimana manusia berinteraksi sangat ditentukan oleh bagaimana kosep kesadaran dan motiv individu seseorang berlangsung dengan tidak menghindarkan eksistensi budaya dan kesadaran diri individu. Konsep kesadaran diri dimaksud akan dimungkinkan dapat dilihat dalam diri individu dalam sebuah komunitas. Perubahan kesadaran dalam diri individu paling berpengaruh dalam interaksi dan komunikasi. Perubahan kesadaran inilah yang akan ditelaah dalam penelitian ini. Kesadaran merupakan inti diri (Mead, 1968) dan sumber identitas (Musgrove 1977 dalam Mulyana, 2004: 229). Kesadaran ini menurut Mead adalah hubungan antara individu dengan lingkungannya sejauh lingkungan itu eksis bagi individu. Kesadaran ini berarti hubungan diri yang mengamati, mengetahui dan berefleksi dengan dunia sosial di sekelilingnya; ia adalah pemahaman manusia atas pengalamannya (Mead 1968 dalam Mulyana, 2004: 299). Yang menjadi masalah dalam penelitian ini adalah bagaimana perubahan identitas religius mahasiswa minoritas dalam komunitas mahasiswa muslim di pascasarjana Unpad, berdasarkan persepsi mereka sendiri?

\section{Teori/Pendekatan}

Dalam penelitian ini digunakan kerangka konseptual interaksionis simbolik untuk mengkaji pengalaman hidup para informan. Meminjam istilah Mulyana (2004: 230), studi ini dapat dianggap sebagai studi emik untuk menelaah makna kultural dari "dalam," analisisnya bersifat idiografik daripada nomotetik. Jadi hasilnya tidak akan dikuantifikasikan dan tidak akan digeneralisasikan kepada seluruh mahasiswa pascasarjana di Universitas Padjadjaran Bandung.

Teori interaksi simbolik dalam konteks penelitian ini dapat menjadi rujukkan untuk menjelaskan proses dan dinamika interaksi yang berlangsung antara mahasiswa non muslim dan mahasiswa muslim di Pascasarjana Unpad. Dua komunitas yang berbeda agama ini diasumsikan sebagai komunitaskomunitas aktif, berinteraksi dengan penuh kreativitas dan dinamisasi. Asumsi ini sejalan dengan tugas atau tujuan teori interaksi simbolik yang mempelajari sifat interaksi yang merupakan kegiatan sosial dinamis manusia, dengan sifat aktif, reflektif, dan kreatif. Perilaku manusia menurut kaum interaksi simbolik ditentukan oleh proses interaksi yang berlangsung di antara mereka.

Interaksi simbolik merupakan suatu teori yang mencoba memandang aktivitas manusia sebagi suatu aktivitas yang khas berupa komunikasi dengan menggunakan (pertukaran) simbol. Kehidupan sosial dalam pandangan kaum interaksi simbolik dimaknai sebagai suatu interaksi manusia dengan menggunakan simbol, dimana simbol tersebut selalu digunakan oleh manusia untuk berkomunikasi dan berinteraksi dengan sesamanya. Di dalam interaksi tersebut juga terjadi upaya saling mendefinisi dan menginterpretasi antara tindakan yang satu dengan yang lainnya (Mulyana, 2004: 71). 
Gambaran di atas cukup untuk mengatakan bahwa teori interaksi simbolik sebagai teori yang humanis, dengan mengakui kebebasan manusia sebagai makhluk yang kreatif dan berpikir. Pengkonstruksian simbol misalnya diklaim sebagai salah satu wujud kebebasan manusia. Sebab dengan cara seperti itu, seorang akan mampu menyusun gagasan dan strategi baru. Individu adalah simbol-simbol yang berkembang melalui interaksi simbol yang mereka ciptakan antar individu (Sukidin, 2002: 20). Manusia diberi kebebasan berpikir dan bertindak sekreatif mungkin. Setiap kalimat adalah ciptaan setiap individu, setiap pidato, pembicaraan telepon, rapat, demonstrasi dan lainnya merupakan kreativitas baru yang dilakukan para pemakai simbol yang memadukan dan menganalisis simbol-simbol dengan caranya yang unik, sehingga kreativitasnya akan selalu muncul dalam setiap situasi (Soeprapto, 2002: 176).

George Ritzer sebagaimana dikutip oleh Mulyana (2004: 73) menformulasikan beberapa prinsip yang menjadi inti dari teori interaksi simbolik, sebagai berikut: Pertama, manusia tidak seperti hewan, karena manusia diberkahi dengan kemampuan berpikir. Kedua, kemampuan berpikir manusia dibentuk oleh interaksi sosial. Ketiga, dalam interaksi sosial orang belajar makna dan simbol yang memungkinkan mereka menerapkan kemampuan berpikirnya yang merupakan kemampuan khas manusia. Keempat, makna dan simbol memungkinkan orang melanjutkan tindakan dan interaksinya yang khas. Kelima, manusia mampu memodifikasi atau mengubah makna dan simbol yang mereka gunakan dalam tindakan dan interaksi berdasarkan interaksi mereka atas situasi. Keenam, kemampuan melakukan modifikasi dan perubahan itu disebabkan oleh kemampuan individu berinteraksi dengan dirinya sendiri lewat berbagai selektivitas hingga proses pemilihan sikap. Ketujuh, pola-pola tindakan dan interaksi yang jalin-menjalin ini membentuk kelompok dan masyarakat.

Berkaitan dengan sumbangsih interaksi individu dalam membentuk masyarakat, Holstein dan Gubrium mengungkapkan (dalam Miller, 2001: 51) bahwa Interaksi simbolik berorientasi pada suatu prinsip dimana setiap individu saling merespon atas suatu makna yang mereka bangun dalam setiap interaksi yang mereka lakukan. Setiap individu secara aktif berhubungan dalam dunia sosialnya sehingga terjadi proses interaksi atau pertukaran sosial budaya di antara mereka. Di samping itu Individu juga dapat dilihat sebagai instrumen terciptanya masyarakat dan budayanya.

Teori interaksi simbolik yang dipelopori oleh Goerge Herbert Mead (1863-1931) ini memusatkan perhatiannya pada interaksi antara individu dan kelompok, dimana individu-individu tersebut berinteraksi secara tatap muka (face to face) dengan menggunakan sign, yang di dalamnya berisi icons, index, dan symbols (Sobur, 2004: 158). Pemikiran simbolik ini pada dasarnya akan membebaskan kita dari pembatasan pengalaman manusia hanya atas apa yang betul-betul kita lihat, dengar atau rasakan. Teori membuat kita terus menerus memikirkan objek secara simbolik (Soeprapto, 2002: 68-70).

Pada dasarnya teori interaksi simbolik termasuk dalam wilayah psikologi sosial yang mengkaji bagaimana dinamika psikis individu dalam berinteraksi dengan individu lainnya. Oleh karena itu kajian awal tentang teori ini harus dimulai dengan teori tentang diri (self) dari "the funding father" interaksi 
simbolik, George Herbert Mead. Diri (self) atau konsep diri dalam pandangan Mead (dalam Mulyana, 2004: 73) adalah suatu proses yang berasal dari interaksi sosial individu dengan orang lain. Atau dalam pemaknaan yang lain, diri sendiri (the self) juga merupakan "obyek sosial" yang kita bagi dengan orang lain dalam suatu interaksi (Soeprapto, 2002: 204). Dengan demikian, konsep diri setiap individu sangat ditentukan oleh bagaimana orang lain melihat atau menilai dirinya saat berinteraksi. Cooley (dalam Mulyana, 2004: 74) mengatakan bahwa konsep diri individu secara signifikan ditentukan oleh apa yang ia pikirkan tentang pikiran orang lain mengenai dirinya. Sebagai konsekwensi dari kehidupan sosial (berkelompok) maka konsep diri seseorang selalu berubah dari kelompok yang satu ke kelompok yang lain, dimana pengaruh kelompok sangat kental bagi interpretasi diri seseorang.

Disamping itu, interaksi simbolik merupakan konstruksi dari beberapa pengertian tentang diri sendiri, tindakan, interaksi, dan obyek (Soeprapto, 2002: 161-164). Dalam berinteraksi dengan diri sendiri, manusia menjadi obyek bagi dirinya. Dalam membentuk tindakan, manusia melakukan dialog internal dalam menyusun konsep dan strategi untuk berhubungan dengan dunia di luar dirinya. Dengan demikian, manusia bukanlah makhluk yang beraksi atas pengaruh lingkungan luar, tetapi bertindak sesuai hasil interpretasi dari dalam dirinya. Menurut Mead bahwa konsepsi diri adalah suatu proses yang berasal dari interaksi sosial individu dengan orang lain. Pandangan Mead tentang diri terletak pada pengambilan peran orang lain (taking the role of the other). Pandangan yang serupa tentang "diri" juga dikemukakan oleh Charles Horton Cooley. Dalam teorinya "the looking-glass self", Cooley berpendapat bahwa konsep diri individu ditentukan oleh apa yang ia pikirkan mengenai pikiran orang lain mengenai dirinya.

Sebagai hasil dari interaksi internal di atas, maka akan menghasilkan tindakan. Sebelum bertindak manusia harus menentukan tujuan, menggambarkan arah tingkah lakunya, memperkirakan situasinya, mencatat dan menginterpretasikan tindakan orang lain, mengecek dirinya sendiri dan lain sebagainya. Berkaitan dengan hal inilah, Mead menyimpulkan bahwa manusia dipandang sebagai organisme aktif yang memiliki hak-hak terhadap obyek yang ia modifikasikan. Tindakan dipandang sebagai tingkah laku yang dibentuk oleh pelaku, sebagai ganti respon yang didapat dari dalam dirinya.

Interaksi dalam pandangan Mead dapat dibedakan antara interaksi nonsimbolik dan interaksi simbolik. Interaksi non-simbolik berlangsung pada saat manusia merespon secara langsung terhadap tindakan dan isyarat dari orang lain, seperti gerak badan, ekspresi dan nada suara. Sedangkan interaksi simbolik dilakukan oleh manusia dengan menginterpretasikan masing-masing tindakan dan isyarat (simbol) orang lain berdasarkan hasil dari interpretasi yang dilakukan oleh dirinya. Interaksi simbolik merupakan proses formatif yang menjadi hak setiap individu, yang menjangkau bentuk-bentuk umum hubungan manusia secara luas.

Obyek bagi Mead merupakan sesuatu yang bisa ditunjuk atau dirujuk, baik yang bersifat nyata maupun abstrak. Ada lima analisis yang berkaitan dengan obyek menurut Mead; (1) alam obyek diambil dari arti yang dimilikinya, yang merupakan hasil ciptaan dari orang yang menganggapnya obyek. (2) arti tersebut 
muncul dari dari bagaimana seseorang tersebut siap bertindak terhadapnya. (3) semua obyek adalah produk sosial dimana di dalamnya dibentuk dan ditransformasi dengan proses pendefenisian yang terjadi dalam interaksi. (4) seseorang akan bertindak berdasarkan obyek tersebut. (5) karena obyek adalah sesuatu yang ditunjuk, maka seseorang bisa bertindak menurut kemauannya terhadap obyek tersebut. Soeprapto (2002: 145) menformulasikan makna obyek menurut kaum interaksi simbolik dalam kehidupan kelompok. Menurutnya, teori interaksi simbolik memandang bahwa kehidupan kelompok manusia adalah sebuah proses dimana obyek-obyek diciptakan, dikukuhkan, ditransformasikan dan bahkan dibuang. Kehidupan dan perilaku manusia secara pasti berubah sejalan dengan perubahan-perubahan yang terjadi di dalam dunia obyek mereka.

Interaksi simbolik memberikan banyak penekanan pada individu yang aktif dan kreatif dalam proses pertukaran simbolnya. Dalam bahasa Herbert Blumer (Soeprapto, 2002: 121), aktor tidak semata-mata beraksi terhadap tindakan yang lain, tetapi dia menafsirkan dan mendefinisikan setiap tindakan orang lain. Respon aktor secara langsung maupun tidak, selalu didasarkan atas penilaian makna tersebut. Oleh karena itu, interaksi manusia dijembatani oleh penggunaan simbol-simbol penafsiran atau dengan menemukan makna tindakan orang lain.

Dalam menjalin komunikasi berdasarkan pada keseragaman makna, manusia dalam interaksi sosial selalu berupaya mencocokkan apa yang ada dalam pikirannya dengan apa yang sedang terjadi pada lingkungan. Artinya manusia dalam proses komunikasi bukan sekadar penerima lambang atau simbol-simbol yang dilihat, didengar atau yang dirabanya secara pasif, melainkan individu secara aktif mencoba mengadakan interpretasi terhadap lambang, simbol atau tanda tersebut. Upaya interpretasi itu adalah bagian interaksi yang dapat dilakukannya dalam rangka menjalin komunikasi yang efektif dan intensif antara pengirim pesan dengan penerima pesan, dan interaksi interpretasi itu tidak hanya dilakukan terhadap pesan yang disampaikan tetapi interaksi interpretasi juga dilakukan terhadap dirinya sendiri, karena orang tidak hanya menyadari orang lain tetapi juga mampu menyadari dirinya sendiri.

Dalam proses ini (Mulyana, 2004: 230), individu mengantisipasi reaksi orang lain, mencari alternatif-alternatif ucapan atau tindakan yang akan ia lakukan. Individu membayangkan bagaimana orang lain akan merespons tindakan mereka. Proses pengambilan peran (taking the role of the other) tersembunyi ini penting, meskipun tidak bisa diamati. Oleh karena itu kaum interaksionis simbolik mengakui tindakan dalam dan tindakan luar, menganggap tindakan luar sebagai lanjutan tindakan dalam. Namun, tindakan luar tidak otomatis menunjukkan tindakan dalam, karena tindakan luar mungkin hanya merupakan pengelolaan kesan (impression management) untuk menyenangkan khalayak tertentu, atau untuk memenuhi tuntutan tertentu yang bersifat sosial, politik, ekonomi dan sebagainya.

\section{Metode dan Prosedur Penelitian}

Penelitian ini dilakukan pada mahasiswa Pascasarjana Unpad angkatan 2005/2006, dengan mewawancarai secara mendalam dan mengamati (observasi) 
mahasiswa yang mempunyai kepercayaan di luar muslim. Wawancara dan pengamatan ini berlangsung lebih dari 2 (dua) bulan (April-Juni 2006). Informan yang dijadikan subjek penelitian ini, mempunyai agama yang berbeda, berasal dari daerah berlainan di Indonesia serta berasal dari suku bangsa yang berbeda pula.

Metode wawancara yang dipakai dalam penelitian ini adalah metode wawancara etnografis atau lebih dikenal dengan istilah wawancara mendalam, agar dapat menggali informasi dari informan secara lebih holistik, utuh, dan mendalam. Dengan metode ini, pewawancara dapat memodifikasi, mengulangi, menguraikan pertanyaan yang ditanyakan dan dapat mengikuti jawaban responden asal saja tidak menyimpang dari tujuan wawancara. Keuntungannya adalah umpan balik segera muncul. Hasil penelitian ini dipaparkan dengan pandangan emik, artinya, uraian yang dikemukakan sesuai hasil wawancara, berdasarkan apa yang dipikirkan, apa yang dirasakan, dan apa yang dilakukan oleh subjek penelitian dalam berkomunikasi dengan kelompok mayoritas, tanpa ada sedikitpun interpretasi apalagi modifikasi pemikiran dari peneliti.

Dalam melakukan wawancara dengan informan hal-hal yang ditanyakan antara lain: bagaimana cara mereka dalam hal ini mahasiswa non muslim berinteraksi dengan komunitas mahasiswa muslim, dalam berinteraksi terutama pada kegiatan yang bersifat formal bagaimana mereka mengerti dan bisa menerima tentang apa yang disampaikan pembicara dengan pendekatan agama Islam, bagaimana mereka membangun hubungan pertemanan terutama menyangkut kebiasaan beribadat antar agama, Kalimat-kalimat apa saja dalam agama Islam yang mereka mengerti maknanya, Bagaimana mereka memadukan kalimat dimaksud dengan kalimat-kalimat dalam agama mereka? Apakah itu bertentangan dengan kepercayaan mereka, dan pengalaman apa saja yang menarik dan berkesan ketika mereka berada dalam komunitas mahasiswa muslim.

\section{Analisis}

\section{Hasil Wawancara}

Pada bagian ini hasil wawancara dipaparkan dalam bentuk yang utuh sesuai jawaban informan, belum diklasifikasikan atau dikategorisasikan. Pada bagian "kategorisasi hasil penelitian" peneliti menandai atau melakukan kategorisasi jawaban informan ke dalam jenis-jenis pernyataan sesuai dengan tipe jawaban, untuk menggambarkan dan memudahkan melihat pandangan informan tentang pola interaksi pertemanan antar agama dominan dan minoritas di kalangan mahasiswa.

Untuk menjaga keselamatan informan dan menghindari sesuatu yang tidak diinginkan, peneliti tidak menyebutkan identitas sebenarnya. Nama yang peneliti cantumkan adalah nama samaran (bukan nama sebenarnya), sedangkan jawaban atau pernyataan informan peneliti paparkan apa adanya sesuai jawaban atau pernyataan informan.

1. Informan yang pertama Suarbawa berusia 27 tahun, statusnya belum berkeluarga berasal dari Bali dan beragama Hindu. Dia merupakan informan kunci dalam penelitian ini, tercatat sebagai mahasiswa program pascasarjana Unpad angkatan 2005/2006. Sejak SLTA sudah berada dalam komunitas 
muslim, Ia menamatkan SLTA dan S1 di Malang Jawa Timur. Dari hasil wawancara, dalam berinteraksi dengan komunitas muslim lebih menekankan bahwa setiap hubungan harus dilandasi dengan pikiran positif, ada rasa keterbukaan dan percaya diri bahwa kita akan diterima oleh orang lain. Dia mengemukakan bahwa sebagaian besar hidup kita selalu berinteraksi dengan komunitas yang berbeda, dia selalu membiasakan diri untuk terbuka akan nilai-nilai positif, kalau kita ingin diterima oleh orang lain maka kita yang terlebih dahulu harus menerima keadaaan orang lain apa adanya.

Kita harus percaya kekuatan kasih sayang yang ada pada setiap manusia, karena dengan kekuatan kasih sayanglah kita bisa hidup berdampingan dengan orang lain. Interaksi dalam hubungan antar manusia jika dikaitkan dengan keyakinan yang berbeda, dia tidak begitu menganggap penting, karena nilai-nilai universal seorang individu tentunya sama, yaitu rasa penghargaan dan kasih sayang pada setiap individu lainnya. Setiap individu itu unik walaupun dengan keyakinan yang sama, tidak ada dua manusia yang sama persis di dunia ini walaupun lahir dengan satu ibu.

Dalam kegiatan rutinitas yang diawali dengan tradisi Islam, misalnya salam, dia yakin walaupun dia tidak tahu arti sebuah salam yang diluar keyakinanan dia, namun dia percaya maksudnya adalah memohon dalam artian positif, seperti kedamaian dan kesejahteraan. Karena tidak mungkin ada keyakinan yang mendoakan orang lain supaya celaka. Perbedaan cara dan bahasa yang digunakan oleh umat lain tidak begitu penting bagi dia, karena yang penting maksud dan tujuannya baik. Seperti Insya Allah, "kalau ga salah artinya mudah-mudahan saya bisa menepati janji dengan menyebut nama Allah." Dan kalau dipadukan dengan ucapan Hindu adalah Om Awignam Astu Namo Sidham, yang artinya dengan memanjatkan doa kepada-Mu, "semoga apa yang akan saya lakukan akan berbuah kebaikan dan berjalan tanpa hambatan. Sehingga menurut dia keyakinan sangat pribadi sifatnya, karena apalah artinya keyakinan yang kuat jika tidak bisa menyesuaikan diri dengan perbedaan orang lain."

Dalam hubungan pertemanan menyangkut kebiasaan beribadah, menurut dia silahkan saja beribadah menurut agama masing-masing. Dan saling mengerti itu adalah kuncinya. Dia sering jalan bersama dengan teman yang berbeda keyakinan dan kalau tepat waktunya mereka harus beribadah dengan waktu yang telah ditetapkan oleh keyakinan mereka, dia biasa menunggu di luar tempat ibadahnya. Ini hal yang biasa dia lakukan, karena dia menghargai keberadaan mereka sebagaimana dia ingin dihargai juga. Dia berpikir ini merupakan sebuah toleransi yang agak susah dilakukan bagi orang lain sekarang ini, dimana ada kecenderungan individu semakin etnosentris terhadap keyakinannya sendiri sehingga menjauhkan diri dari nilai penghargaan terhadap manusia. Dalam beribadah tentunya memiliki cara yang berbeda sesuai dengan keyakinan kita, dan secara jujur dia katakana bahwa mungkin saja dia bukan termasuk orang yang terlalu fanatik terhadap cara beribadah dalam keyakinannya (Hindu). "Saya pikir saya bisa melakukan dengan cara sesederhana mungkin yang penting itu dilandasi dengan perasaan tulus suci kepada-Nya." 
Muslim adalah agama luhur dengan filosofi yang tinggi karena mengajarkan nilai-nilai kebaikan, dan ini dapat dia rasakan dari cara pergaulan teman-teman muslim. Dia sering mengucapkan salam Islam ketika berkunjung ke rumah teman muslimnya dan juga sering mengucapkan Insya Allah, dan itu biasa agar dapat bisa diterima secara total oleh teman-teman muslim. Walaupun ada bagi teman-teman tertentu menurut dia, terkesan sangat fanatik terhadap ajaran-ajaran Islami. Dan menurut dia mereka kurang bisa menerapkan sesuai dengan konteks realitas. Terkadang menurut dia mereka kurang bergaul dengan dunia luas yang mampu memahami arti sebuah perbedaan, sehingga kaca mata kuda yang mereka pergunakan sangat mempengaruhi sikap mereka terhadap pergaulannya dengannya. Tidak akan ada individu yang menjadi sama persis di dunia ini, walaupun dijejali dengan ajaran-ajaran yang sama dalam hidupnya. Semua akan kembali lagi pada tingkat persepsi masing-masing individu dalam mempraktekkan nilai-nilai ajaran dari keyakinannya.

2. Informan yang kedua Gunawan 25 tahun, masih lajang yang beragama Kristen Katolik berasal dari Jawa Tengah. Dia adalah mahasiswa pascasarjana Unpad angkatan 2005/2006. Dia tinggal di Bandung sejak kuliah S1 tepatnya tahun 2000, selalu tinggal dikontrakan yang dominan dengan mahasiswa muslim. Dalam berinteraksi dengan mahasiswa muslim bagi dia biasa aja, selama kita saling pengertian maka hubungan pertemanan akan berlangsung mulus. Dalam berinteraksi dia lebih menekankan bahwa jangan campurkan antara teologi dan pertemanan, agama adalah sebuah keyakinan individual sedangkan pertemanan adalah sebuah hubungan sosial yang tidak bisa terhindarkan. Maka akan susah dalam sebuah pertemanan kalau kita menggunakan batasan teologi sebagai rambunya. Berpikir positif, bahwa dalam setiap agama diajarkan kebaikan yang sama.

Selama berada dalam komunitas muslim, baik dalam perkuliahan, pergaulan maupun kegiatan yang bersifat formal dengan acara-acara tertentu yang menggunakan tradisi Islam, baginya itu tidak jadi masalah. Misal ketika pertemuan diawali dengan ucapan Assalamu'alaikum $W r . W b$, maka di bawah alam sadar dia akan mencari apa makna yang sama yang terkandung dalam ucapan salam tersebut. Dia katakan itu tidak bertentangan, kalau salam Islam mengisyaratkan bahwa semoga keselamatan selalu menyertai kita seru sekailan alam, di Katolikpun artinya juga sama yaitu salam damai sejahtera bagimu dan keluargamu. Perbedaan jangan dijadikan penghalang dalam pertemanan demikian ungkapnya. Islam dan Katolik tidak ada bedanya, karena Islam dan Katolik berasal dari budaya yang sama, dan awalnya menggunakan bahasa yang sama. Islam adalah agama toleran yang berasal dari budaya tinggi terbukti dengan simbol-simbol kebesaran Islam pada masa lalu.

Dalam berinteraksi dengan teman-teman muslim dia sering mengingatkan ketika masuk waktu shalat, dan itulah toleransi dalam kepercayaan dan tidak bertentangan dalam sebuah keyakinan, begitupun teman-teman muslim juga meperlakukan hal yang sama terhadap agama yang dia anut.Bagi dia, Islam adalah agama dengan budaya tinggi, banyak 
kontribusi Islam terhadap perkembangan sejarah dunia yang mestinya medapat penghargaan. Dia tertarik dengan pemikir Islam terutama Ibnu Khaldun dan Al Ghazali, menurutnya mereka adalah pemikir sejati yang semestinya dihargai oleh Zionis Barat.

3. Informan yang ketiga Erick 23 tahun, beragama Kristen Protestan juga belum menikah. Berasal dari Jakarta yang ikut orang tua kerja di sana. Asli keluarganya adalah berasal dari Media Sumatera Utara. Dia tinggal di komunitas muslim sejak kecil sampai sekarang. Dia adalah mahasiswa pascasarjana Unpad. Bagi dia dalam berinteraksi dengan komunitas muslim menurut dia tidak harus dipermasalahkan, semua kembali kepada hati dan niat yang penting saling mengisi dalam kesadaran diri. Bagi dia agama adalah sebuah kekuatan pragmatis yang apabila tidak dikembangan saling menghargai, maka akan terjadi kesenjangan dalam pertemanan. Biarkan saja kebebasan yang melandasai hubungan pertemanan, kita sama-sama punya agama. Agamamu adalah agamamu dan agamaku adalah agamaku, "yang mau shalat yaaa...silahkan shalat, yang mau kebaktian ya silahkan kebaktian karena kita sudah punya ajaran masing-masing."

Dalam pergaulan sehari-hari, terutama dalam kegiatan-kegiatan yang bersifat formal silahkan saja menggunakan tradisi agama muslim, yang penting saling menguntungkan, muslim dihargai dengan dominannya dan Kristen bisa memahami karena itu sudah menjadi kebiasaan. Ujarnya mempertegas "selama tidak mengganggu ok-ok saja." Kalimat-kalimat Islam yang diucapkan seperti salam bagi dia silahkan saja diucapkan karena itu ajaran muslim. Yang non muslim diam dan menghargai akan lebih bermanfaat daripada saling usil, karena menurut dia setiap ucapan dalam agama adalah sebuah doa yang menuju kejalan kebaikkan.

Dalam berinteraksi dalam hubungan pertemanan menyangkut kebiasaan beribadah, kita silahkan saja mengerjakan agama masing-masing di manapun tempatnya tidak jadi masalah. Islam adalah sebuah ajaran yang sangat luar biasa, dia kagum dengan keunikan Islam dan saling menghargai yang diajarkan dalam Islam. Di akhir wawancara, dia mengungkapkan dia tertarik dengan Islam dan dia ingin belajar banyak tentang budaya Islam.

4. Kristina 25 tahun informan yang terakhir. Masih gadis, beragama Kristen Protestan, berasal dari Batak Karo Sumatera Utara. Ia adalah mahasiswa program pascasarja Unpad adalah seorang aktivis Gereja. Baru pertama kali pisah dengan keluarga. Dalam melakukan wawancara dengan informan yang satu ini, peneliti mengalami sedikit kesulitan karena sang informan sangat dibatasi oleh konsep agamanya dalam menjawab pertanyaan-pertanyaan yang peneliti ajukan.

Dari hasil wawancara, bagi dia dalam berinteraksi dengan komunitas muslim, selama itu saling menguntungkan dan tidak mengganggu dalam hubungan keagamaan wajar-wajar saja, kenapa harus dihindari, tapi yang paling penting saling menguntungkan. Bagi dia, dalam kegiatan-kegiatan yang bersifat formal terutama dengan tradisi Islam, dia sering merasa risih sendiri, karena dengan jujur Ia mengatakan itu menjadi masalah besar dalam dirinya. 
"Kenapa kegiatan tidak secara umum saja prosesnya kan tidak saling bertentangan dalam keyakinan masing-masing."

Dalam berinteraksi dalam proses pertemanan, dia dengan jujur mengatakan agak terganggu kalau ada yang saling mengganggu, misalkan saja lagi jalan-jalan ada temannya yang muslim mau izin shalat. Namun di balik kekuatannya dalam memegang ajaran kristiani, sebagai manusia yang selalu berubah konsep dan kesadaran diri dalam berinteraksi, dia sangat terkesan dengan agama Islam yang sangat fleksibel, dan nilai toleransi yang begitu tinggi. Dengan kondisinya yang minoritas ternyata Islam mampu menerimanya secara utuh dalam pertemanan, Islam sangat luar biasa dan Islam adalah agama yang sangat istimewa. Tidak ada kekerasan dalam Islam, walau akhir-akhir ini banyak kekuatan-kekuatan yang mengatasnamakan Islam yang merongrong Islam dari dalam. Menurut dia itu adalah bukan Islam melainkan sebuah aliran yang terlalu sempit memahami sebuah ajaran agama. Sekali lagi Islam adalah agama fleksibel dan toleran.

\section{Kategorisasi Hasil Penelitian}

Dari hasil penelitian yang dilakukan melalui observasi dan wawancara, menyangkut interaksi mahasiswa minoritas dalam komunitas Muslim, maka dalam penelitian ini dapat ditarik suatu konstruk yang berkaitan dengan interaksi mahasiswa minoritas dalam komunitas mahasiswa muslim sebagai berikut:

1. Mahasiswa Toleran

Mahasiswa non Muslim dalam berinteraksi dengan mahasiswa Muslim yang dominan, lebih mengembangkan konsep dirinya pada keterbukaan dan saling menghargai serta menerima keberadaan agama lain. Beberapa informan mengemukakan bahwa Muslim adalah agama luhur dengan filosofi yang tinggi yang mengajarkan nilai-nilai kebaikan, dan ini dapat dirasakan dari cara pergaulan teman-teman muslim (Suarbawa). Islam adalah agama toleran yang berasal dari budaya tinggi (Gunawan) dan Islam adalah agama yang fleksibel dan toleran (Kristina), demikian pandangan informan tentang Islam.

Toleran di sini dimaksudkan bahwa dalam berinteraksi dengan komunitas Islam yang dominan, mahasiswa minoritas lebih mengedepankan saling mengahargai dalam aktivitas keagamaan, sehingga hubungan pertemanan berjalan dengan selaras. Sikap toleransi di dalam diri ini terungkap melalui aktivitas dalam pertemanan sehari-hari, ucapan mengingatkan teman muslim bila masuk waktu shalat dan memberikan kebebasan di antara keduanya dalam menjalankan rutinitas keagamaan yang membingkai sebuah kesadaran diri.

"Saya sering jalan bersama dengan teman yang berbeda keyakinan, kalau tepat waktunya mereka harus beribadah, saya biasa menunggu di luar tempat ibadah mereka yang berbedah keyakinan dengan saya, terutama hal ini sering saya alami kalau lagi jalan dengan teman-teman muslim" (Suarbawa).

Uraian ini menjelaskan bahwa makna toleran adalah bagaimana penganut sebuah agama membuka diri saling menghargai perbedaan agama dan menghormati pemeluk agama yang bersangkutan melakukan rutinitas 
agamanya, seperti yang dikemukakan informan "bahwa perbedaan jangan dijadikan penghalang dalam pertemanan" (Gunawan). Makna toleran di sini adalah adanya saling menghargai dan saling membuka diri dalam menerima keberadaan agama lain, yang menentukan bentuk sebuah hubungan mahasiswa antar agama.

2. Mahasiswa Fanatik

Dalam kategori ini peneliti menemukan bahwa, dalam hubungan pertemanan antar agama di kalangan mahasiswa, ada saja dominasi agama yang menjadi batas dalam sebuah interaksi. Kekuatan suatu agama ikut bermain dalam diri seseorang yang bersifat subjektif dalam menjalin hubungan interaksi antar masyarakat, terutama menyakut tradisi suatu agama. Hal ini sebagaimana peneliti temukan dalam wawancara dengan informan, seperti yang diungkapkan oleh Kristina:

"Dalam kegiatan-kegiatan yang bersifat formal terutama dengan tradisi Islam, saya sering merasa risih sendiri, jujur saja itu menjadi masalah besar dalam diri saya. Kenapa kegiatan tidak secara umum saja prosesnya kan tidak saling bertentangan dalam keyakinan."

Dalam ungkapan yang lain Gunawan mengemukakan "dalam berinteraksi jangan campurkan antara teologi dan pertemanan, agama adalah sebuah keyakinan individual sedangkan pertemanan adalah sebuah hubungan sosial yang tidak bisa terhindarkan."

Dari ungkapan di atas, ada makna yang terkandung bahwa fanatisme agama juga menjadi penentu keeratan hubungan pertemanan antar mahasiswa non muslim dengan mahasiswa muslim. Fanatik di sini dipahami bahwa kekuatan agama memberi ruang tersendiri dalam sebuah interaksi antar agama, yang memegang teguh ajaran sebuah agama. Kesadaran diri yang terbangun dalam sebuah hubungan merupakan kesadaran diri yang terkonstruk oleh ajaran-ajaran Ilahiyah.

3. Mahasiswa Pragmatis

Konsepsi pragmatis di sini dipahami sebagai sebuah konstruk dari sebuah realitas, bahwa hubungan pertemanan mahasiswa yang berbeda agama lebih menekankan pada interaksi yang bersifat hedonis. Sebagaimana ungkapan informan selama tidak mengganggu sah-sah saja, selama itu menguntungkan kenapa tidak diikuti.

Pada sisi yang lain hubungan pragmatis, juga berlangsung dengan mengikuti kebiasaan dan kelaziman sebuah agama. Dengan tujuan untuk dapat diterima dalam pertemanan pada kesadaran diri informan. Salah satu informan yaitu Suarbawa, dia sering mengucapkan salam Islam ketika berkunjung ke rumah teman muslimnya dan juga sering mengucapkan Insya Allah. Walaupun ada bagi teman-teman tertentu, terkesan sangat fanatik terhadap ajaran-ajaran Islami, dan menurut dia mereka kurang bisa menerapkan sesuai dengan konteks realitas.

Dalam konstruk yang ketiga ini bahwa interaksi minoritas agama dalam komunitas muslim, lebih menekankan pada hal-hal yang bersifat pragmatis semata selama itu menguntungkan dan tidak saling mengganggu. Tidakan yang merupakan inti dasar dalam interaksi simbolik juga menjadi 
warna dalam menarik sebuah konstruk. Maka dengan alasan ini pulalah peneliti mengemukakan bahwa sebuah konstruk interaksi hubungan antar muslim dominan dan non muslim yang minoritas merupakan pengembangkan konsep hubungan yang bersifat pragmatis.

\section{Kesimpulan}

Pola interaksi mahasiswa minoritas (non muslim) dalam komunitas muslim di pascasarjana Unpad menunjukan sebuah realitas yang terkonstruk dalam diri individu informan. Menunjukkan bahwa kekuatan agama dalam interaksi antar agama tidak serta merta membatasi ikatan pertemanan di kalangan mahasiswa. Sikap terbuka dan kesan positif terhadap agama lain ikut andil dalam hubungan pertemanan di kalangan mahasiswa minoritas dalam membentuk konsep kesadaran diri.

Proses interaksi di kalangan mahasiswa yang berbeda agama dalam mengembangkan hubungan, terbagi atas hubungan atas landasan fanatisme agama, toleransi agama dan pragmatisme agama. Mengilhami peneliti memunculkan konstruk dalam penelitian ini menjadi tiga kategori, yaitu mahasiswa toleran, mahasiswa fanatik dan mahasiswa pragmatis. Dari ketiga kategori konstruk ini menjadi penentu, bagaimana pola interaksi mahasiswa minoritas dalam komunitas muslim, khususnya pada program pascasarjana Unpad Bandung angkatan 2005/2006.

$* * * *$

\section{Daftar Pustaka}

Devito, Joseph, A. 1997. Komunikasi Antarmanusia; Kuliah Dasar, Penerj. Agus Maulana. Jakarta: Professional Books.

Fisher, B. Aubrey, 1986, Teori-Teori Komunikasi, Penerj. Soejono Trimo. Bandung: Remaja Rosdakarya.

Mulyana, Deddy. 2005. Ilmu Komunikasi; Suatu Pengantar. Bandung: Remaja Rosdakarya.

-----------. 2004. Metodologi Penelitian Kualitatif: Paradigma Baru Ilmu Komunikasi dan Ilmu Sosial lainnya. Bandung: Remaja Rosdakarya.

Sobur, Alex. 2004. Semiotika Komunikasi. Bandung: Remaja Rosdakarya.

Soeprapto, Riyadi. 2002. Interaksionisme Simbolik; Perspektif Sosiologi Modern. Yogyakarta: Pustaka Pelajar.

Spradley. 1997. Metode Etnografi. Yogyakarta: Tiara Wacana.

Sukidin, Basrowi. 2002. Metode Penelitian Kualitatif Perspektif Mikro. Surabaya: Insan Cendekia. 
Thadi, R. INTERPRETASI AUDIEN TERHADAP SAJIAN DAKWAHTAINMENT DI TELEVISI (Studi Program "Ceramah Religi" dan "Sinetron Religi" dalam Interpretasi. 